\title{
Feldspar and Oxide Thermometry of Granulites in the Adirondack Highlands*
}

\author{
S.R. Bohlen and E.J. Essene \\ Department of Geology and Mineralogy, The University of Michigan, Ann Arbor, Michigan, \\ U.S.A.
}

\begin{abstract}
Thermometry of regionally metamorphosed granulites of the Adirondack Highlands has been undertaken using feldspar and iron-titaniumoxide equilibria. Electron microprobe analyses of 20 coexisting oligoclase $\left(\mathrm{An}_{18-30}\right)$ and microcline perthite $\left(\mathrm{Or}_{57-87}\right)$ pairs from charnockites and granitic gneisses give $\mathrm{K}_{\mathrm{D}}\left[\mathrm{Na} /(\mathrm{Na}+\mathrm{Ca}+\mathrm{K}]_{\text {plag }} /[\mathrm{Na} /(\mathrm{Na}+\mathrm{Ca}+\mathrm{K})]_{\text {or }}=2-3\right.$ yielding temperatures of $650^{\circ}$ to $750^{\circ} \mathrm{C}$ in comparison to Seck's (1971) experimental and Stormer's (1975) calculated temperatures for inferred pressures of 8 kilobars. Microprobe analyses of 10 coexisting titaniferous magnetite (ulvöspinel ${ }_{\mathrm{ss}}$ 16-45) and ilmenite (hematite ss $_{\text {s. }}$ 4.7-6.5) pairs from the Marcy massif anorthosite and related gabbros give temperatures of $620^{\circ}$ to $800^{\circ} \mathrm{C}$ in comparison to Buddington and Lindsley's (1964) experimental data. Oxygen fugacities buffered by this assemblage range between $10^{-20}$ and $10^{-16}$ and always lie within $10^{+1}$ of the $f_{\mathrm{O}_{2}}$ buffered by fayalite-magnetite-quartz. Exsolved albite in alkali feldspar and ilmenite (oxidized ulvöspinel lamellae) must be reintegrated to infer metamorphic temperatures. Both thermometers give internally consistent, reproducible and geologically reasonable results. The inferred $750^{\circ}$ and $700^{\circ} \mathrm{C}$ isotherms wrap around the anorthosite massif in roughly concentric circles. Maximum metamorphic temperatures $\left(790 \pm 50^{\circ} \mathrm{C}\right)$ occur between Saranac Lake and Tupper Lake, New York.
\end{abstract}

\section{Introduction}

Accurate, detailed thermometry is essential to the interpretation of events in metamorphic terranes. Often other important parameters such as pressure and fugacities of water and other gas species cannot be quantified if temperatures are now known or are only approximately known. Consequently experimenters

\footnotetext{
Contribution No. 336 from the Mineralogical Laboratory, Department of Geology and Mineralogy, The University of Michigan, Ann Arbor, Michigan, 48109, U.S.A.
} 
have expended great effort in calibrating temperature-dependent systems within common rock-forming assemblages. Thermometers such as calcite-dolomite, magnetite-ilmenite, coexisting feldspars, biotite-magnetite-Kspar and coexisting pyroxenes have been calibrated to date. Theoretically these should be sufficient to establish regional temperature variations in a large variety of metamorphic rocks. The unhappy reality is that in metamorphic rocks as well as in many igneous rocks these temperature-sensitive systems are plagued by disequilibrium, rapid reequilibrium, ex-solution, etc., which can severely limit their usefulness. This paper discusses how reequilibration features can be corrected for in the two-feldspar and iron-oxide systems to obtain peak metamorphic temperatures in rocks from the Adirondack Highlands. Temperature data presented here will form a basis for future work on pressures, fluid compositions and reaction equilibria in the granulite facies metamorphics of the Adirondack Highlands.

Ever since Buddington and Lindsley's (1964) classical paper calibrating the temperature- $f_{\mathrm{O}_{2}}$ dependence of coexisting ulvöspinel-magnetite and ilmenitehematite solid solutions, these coexisting oxides have been used to obtain temperature and oxygen fugacity data in many geological systems. Buddington and Lindsley originally applied this thermometer to many igneous and metamorphic rocks including some Adirondack amphibolites and granulites. Carmichael (1967), Carmichael and Nicholls (1967) and Stormer and Whitney (1976) have successfully applied the oxide thermometer to volcanic and hypabyssal intrusives where coexisting titaniferous magnetite and ferrian ilmenite have quenched rapidly and have not substantially reequilibrated or exsolved. This thermometer is probably not as accurate for temperature ranges of most extrusive rocks $\left(900-1100^{\circ} \mathrm{C}\right)$ compared to high-grade metamorphic temperatures $\left(600-800^{\circ} \mathrm{C}\right)$ due to the more acute intersection of isopleths contouring ulvöspinel $\mathrm{ss}_{\mathrm{ss}}$ in magnetite and hematite ss $_{\text {in }}$ ilmenite at those high temperatures as well as to the greatly increased solution of impurities such as $\mathrm{Mn}, \mathrm{Mg}, \mathrm{Al}, \mathrm{Nb}$, etc. Although perhaps ideally suited for metamorphic rocks, reequilibration, exsolution and disequilibrium, common in these rocks, can render the iron-titanium-oxide thermometer useless if these effects are ignored.

The feldspar thermometer first proposed by Barth (1934) has long been recognized as a potentially powerful method for obtaining temperatures in igneous and metamorphic rocks. Even though many modifications have been proposed (Barth, 1951, 1962, 1968; Orville, 1962; Perchuk and Ryabchikov, 1968), only recently has it been modelled using thermodynamic data which considers nonideality in alkali feldspars and pressure dependence of the distribution of $\mathrm{NaAlSi}_{3} \mathrm{O}_{8}$ between coexisting alkali and plagioclase feldspars (Stormer, 1975; Whitney and Stormer, 1976). The effect of $\mathrm{K}$ in plagioclase and $\mathrm{Ca}$ in alkali feldspar has yet to be considered. Their effect on temperature determinations is unknown though presumably their presence does not affect the results significantly. Stormer's calculated feldspar miscibility fits Secks's (1971) solvus at $650^{\circ} \mathrm{C}$ for 1,5 and 10 kilobars to $\pm 20^{\circ} \mathrm{C}$ for plagioclase $\mathrm{An}_{5-42}$ but appears to give much larger errors for more calcic plagioclases. Though the proposed thermometer has been tested in both igneous and metamorphic rocks and is consistent with other thermometers, its application is not straightforward in garnet granulite facies rocks of the Adirondacks. Substantial reequilibration 


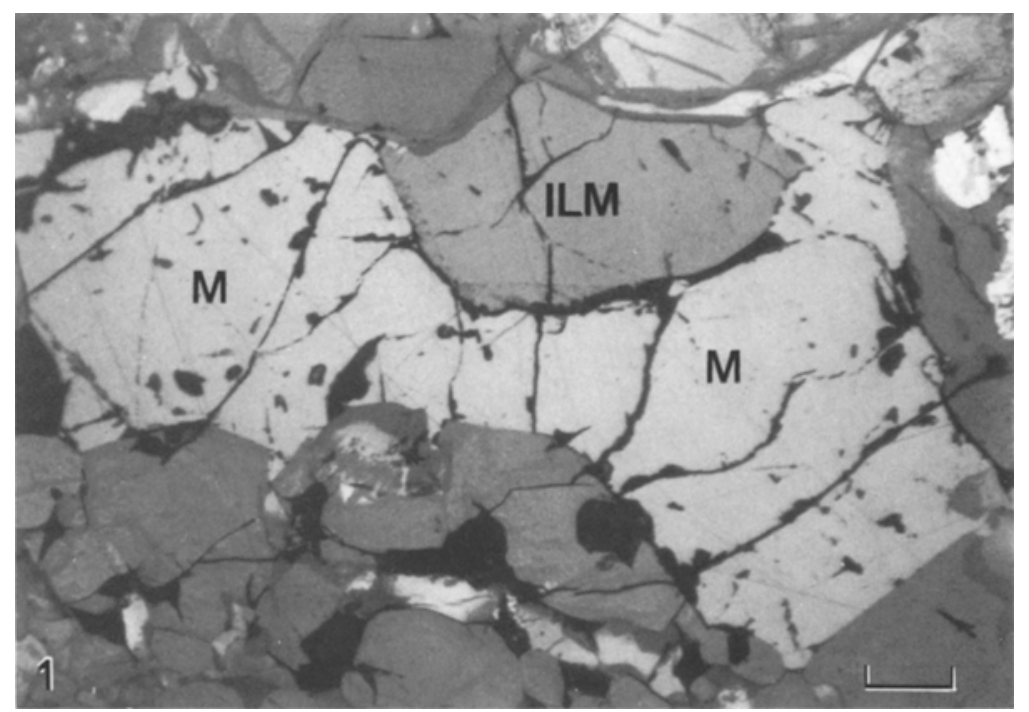

Fig. 1. "Exsolved" ilmenite (ILM) granule-magnetite $(M)$ intergrowth. The bar at the lower right is $100 \mu$

and coarse exsolution of albite in alkali feldspar are common. In order to apply the feldspar thermometer to rocks from the Adirondacks the exsolved albite must be reintegrated. The composition obtained is assumed to have equilibrated with its coexisting plagioclase at or near the peak of metamorphism. Temperatures are inferred on the basis of the reintegrated Kspar and plagioclase compositions.

The Adirondacks are a southern extension of the Grenville Province which have undergone upper amphibolite to garnet granulite facies metamorphism (Engel and Engel, 1958, 1962). The dominant feature of the Adirondacks is the anorthosite massif covering some 2000 square kilometers. Associated with the anorthosite massif are a wide variety of lithologic types ranging from charnockites, granitic gneisses to mafic gabbros. Many of the orthogneisses are considered to be genetically related and are generally referred to as the anorthositecharnockite suite (De Waard, 1965, 1966, 1968; Buddington, 1939; Buddington and Leonard, 1962). Specimen descriptions and information on sample localities are compiled in Appendix I. Most of the samples used in this study are not anorthosite because associated charnockites and quartz-saturated mafic gabbros provided more useful assemblages. Anorthosite and mafic anorthosite most often do not contain coexisting feldspars or iron-titanium oxides.

Saturated mafic gabbros, norites and amphibolites from the Adirondack Highlands often contain variable amounts of plagioclase $\left(\mathrm{An}_{20}-\mathrm{An} \mathbf{n}_{50}\right)$, orthopyroxene $\left(\mathrm{Fs}_{40-90}\right)$, clinopyroxene $\left(\mathrm{Hd}_{30-75}\right)$, almandine-rich garnets, and pargasitic hornblendes with minor quartz and occasionally biotite and alkali feldspar. Coexisting magnetite and ilmenite are common, though ilmenite is often the only oxide phase present. 
Table 1. Ilmenites and "exsolved" ilmenites from the Adirondack Highlands

\begin{tabular}{|c|c|c|c|c|c|c|c|c|}
\hline & $\begin{array}{l}\text { TP-5 } \\
\text { Exol }\end{array}$ & TP-5 & $\begin{array}{l}\text { TP-11 } \\
\text { Exol }\end{array}$ & TP-11 & $\begin{array}{l}\text { IN-10 } \\
\text { Exol }\end{array}$ & IN-10 & $\begin{array}{l}\text { N-5 } \\
\text { Exol }\end{array}$ & $\mathrm{N}-5$ \\
\hline $\mathrm{TiO}_{2}$ & 49.49 & 49.36 & 50.65 & 49.25 & 49.76 & 48.30 & 51.20 & 49.67 \\
\hline $\mathrm{Al}_{2} \mathrm{O}_{3}$ & 3.00 & 0.00 & 0.21 & 0.14 & 1.68 & 0.05 & 0.33 & 0.03 \\
\hline $\mathrm{FeO}^{\mathrm{a}}$ & 44.56 & 48.44 & 45.89 & 49.27 & 44.48 & 47.82 & 46.88 & 49.10 \\
\hline $\mathrm{FeO}$ & 42.17 & 42.67 & 43.55 & 43.29 & 42.81 & 42.95 & 44.90 & 43.85 \\
\hline $\mathrm{Fe}_{2} \mathrm{O}_{3}$ & 2.65 & 6.40 & 2.58 & 6.63 & 1.86 & 5.41 & 2.10 & 5.83 \\
\hline $\mathrm{MnO}$ & 2.09 & 1.17 & 1.62 & 0.73 & 2.57 & 0.92 & 0.97 & 0.35 \\
\hline $\mathrm{MgO}$ & 0.13 & 0.30 & 0.14 & 0.21 & 0.20 & 0.28 & 0.03 & 0.20 \\
\hline SUM & 99.27 & 99.55 & 98.51 & 99.60 & 98.69 & 97.37 & 99.41 & 99.36 \\
\hline SUM & 99.53 & 99.90 & 98.75 & 100.3 & 98.88 & 97.91 & 99.62 & 99.93 \\
\hline \multicolumn{9}{|c|}{ Formulae normalized about 2 cations } \\
\hline $\mathrm{Fe}^{2+}$ & 0.882 & 0.903 & 0.932 & 0.909 & 0.891 & 0.916 & 0.953 & 0.928 \\
\hline $\mathrm{Fe}^{3+}$ & 0.050 & 0.122 & 0.048 & 0.130 & 0.039 & 0.104 & 0.040 & 0.111 \\
\hline $\mathrm{Ti}$ & 0.931 & 0.939 & 0.973 & 0.933 & 0.955 & 0.947 & 0.975 & 0.945 \\
\hline $\mathrm{Mn}$ & 0.044 & 0.025 & 0.035 & 0.016 & 0.056 & 0.020 & 0.021 & 0.007 \\
\hline $\mathrm{Mg}$ & 0.005 & 0.011 & 0.006 & 0.008 & 0.008 & 0.011 & 0.001 & 0.008 \\
\hline Al & 0.088 & 0.000 & 0.006 & 0.004 & 0.051 & 0.002 & 0.010 & 0.001 \\
\hline$\%$ HEM & 2.8 & 6.3 & 2.6 & 6.5 & 1.9 & 5.4 & 2.1 & 5.6 \\
\hline Vol. \% & 22.8 & & 19.0 & & 22.9 & & 21.8 & \\
\hline
\end{tabular}

a Total $\mathrm{FeO}$. The amount $\mathrm{Fe}_{2} \mathrm{O}_{3}$ is calculated from stoichiometry. The sum of oxides is calculated for total iron as $\mathrm{FeO}$ and for the calculated wt. $\% \mathrm{Fe}_{2} \mathrm{O}_{3}$ (bottom sum)

Granitic gneisses, charnockites and other related rocks are generally composed of coarse-grained microcline-perthite, oligoclase, orthopyroxene and quartz with minor hornblende, clinopyroxene, biotite and garnet. Iron-titanium oxides are less common in more felsic rocks, and consequently it is difficult to obtain feldspar and oxide temperatures using the same hand specimen.

\section{Iron-Titanium Oxide Geothermometry}

Buddington and Lindsley (1964) calibrated the $f_{\mathrm{O}_{2}}-T$ dependence of coexisting magnetite-ulvöspinel and ilmenite-hematite solid solutions. During their experimental calibration Buddington and Lindsley observed ilmenite "exsolution" lamellae in magnetite, in many of their charges. They also observed the same phenomena in many natural phases. This was not, however, interpreted strictly as exsolution, but rather a subsolidus oxidation of the ulvöspinel component in magnetite to form ilmenite by the schematic reaction:

$$
6 \mathrm{Fe}_{2} \mathrm{TiO}_{4}+\mathrm{O}_{2}=2 \mathrm{Fe}_{3} \mathrm{O}_{4}+6 \mathrm{FeTiO}_{3} \text {. }
$$

The reaction is more accurately described as ulvöspinel-rich $\mathrm{ss}_{\mathrm{s}}+\mathrm{O}_{2}=$ magnetitericher $_{s s}+$ ilmenite $_{s s}$. The potential for gamma $\mathrm{FeTiO}_{3}$ solid solution in magnetite is extremely limited at geologic temperatures, and as a result any $\mathrm{Ti}$ originally 


\begin{tabular}{|c|c|c|c|c|c|c|c|}
\hline $\begin{array}{l}\text { MM-13 } \\
\text { Exol }\end{array}$ & MM-13 & $\begin{array}{l}\text { SR-31 } \\
\text { Exol }\end{array}$ & SR-31 & & 76-AS-1 & $\begin{array}{l}\text { LB-1 } \\
\text { Exol }\end{array}$ & LB-1 \\
\hline 50.58 & 50.01 & 51.82 & 49.25 & & 50.07 & 48.94 & 49.81 \\
\hline 1.37 & 0.01 & 0.12 & 0.88 & & 0.00 & 0.48 & 0.06 \\
\hline 44.97 & 48.44 & 47.22 & 46.98 & 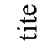 & 46.57 & 48.80 & 47.89 \\
\hline 44.08 & 43.98 & 44.58 & 42.75 & $\stackrel{\Delta}{\Xi}$ & 43.15 & 44.97 & 43.36 \\
\hline 0.99 & 4.95 & 2.93 & 4.70 & 可 & 3.80 & 4.25 & 5.02 \\
\hline 1.33 & 0.81 & 0.95 & 1.47 & $\sum$ & 2.17 & 1.44 & 1.26 \\
\hline 0.10 & 0.12 & 0.59 & 0.01 & $\stackrel{\infty}{3}$ & 0.01 & 0.02 & 0.10 \\
\hline 98.35 & 99.39 & 100.7 & 98.59 & E. & 98.82 & 99.68 & 99.12 \\
\hline 98.45 & 99.98 & 101.0 & 99.06 & 焉 & 99.20 & 100.1 & 99.61 \\
\hline 0.935 & 0.930 & 0.929 & 0.911 & $\stackrel{8}{\varrho}$ & 0.920 & 0.914 & 0.920 \\
\hline 0.023 & 0.097 & 0.055 & 0.088 & $\overline{8}_{0}$ & 0.073 & 0.093 & 0.096 \\
\hline 0.968 & 0.952 & 0.971 & 0.942 & $\stackrel{\varrho}{\Xi}$ & 0.960 & 0.946 & 0.951 \\
\hline 0.029 & 0.017 & 0.020 & 0.033 & $\stackrel{\overline{0}}{\varrho}$ & 0.047 & 0.031 & 0.027 \\
\hline 0.044 & 0.004 & 0.022 & 0.000 & & 0.000 & 0.001 & 0.004 \\
\hline 0.041 & 0.000 & 0.003 & 0.026 & & 0.000 & 0.015 & 0.002 \\
\hline 1.0 & 4.8 & 2.9 & 4.7 & & 3.8 & 4.6 & 4.7 \\
\hline 22.6 & & 31.3 & & & & 10.5 & \\
\hline
\end{tabular}

dissolved in magnetite must have been in solid solution in stoichiometric ulvöspinel-magnetite instead.

Subsolidus oxidation of the ulvöspinel component results in two common types of "exsolution" textures. Granule "exsolution" (Fig. 1) appears as small grains of ilmenite surrounding or nearly surrounding the magnetite. Rarely coarse blebs of ilmenite are enclosed within magnetite. These contrast with the much larger ilmenite grains which coexist with the magnetite-ilmenite intergrowths but most often bear no textural relation to magnetite. Buddington and Lindsley argue that ilmenite granules associated with magnetite are a result of diffusion of ilmenite components to a grain boundary and oxidation to ilmenite. This interpretation seems supported by our microprobe analyses which indicate that the two generations of ilmenite have different minor element compositions (Table 1). Subsolidus oxidation of ulvöspinel component can also explain the origin of sandwich or trellis type ilmenite "exsolution" lamellae in magnetite (Fig. 2). Again these ilmenite lamellae have different compositions than the primary ilmenites unassociated texturally with magnetite, and the exsolution/oxidation interpretation is plausible. Another texture, magnetite intergrowths parallel to the basal plane of ilmenite, has been interpreted by Buddington et al. (1964) as a subsolidus reduction of hematite to magnetite. This texture is rarely observed by the writers in the Adirondacks. The analyzed primary ilmenites have only 4.6-6.7 mole \% hematite solid solution and presumably have only small potential 


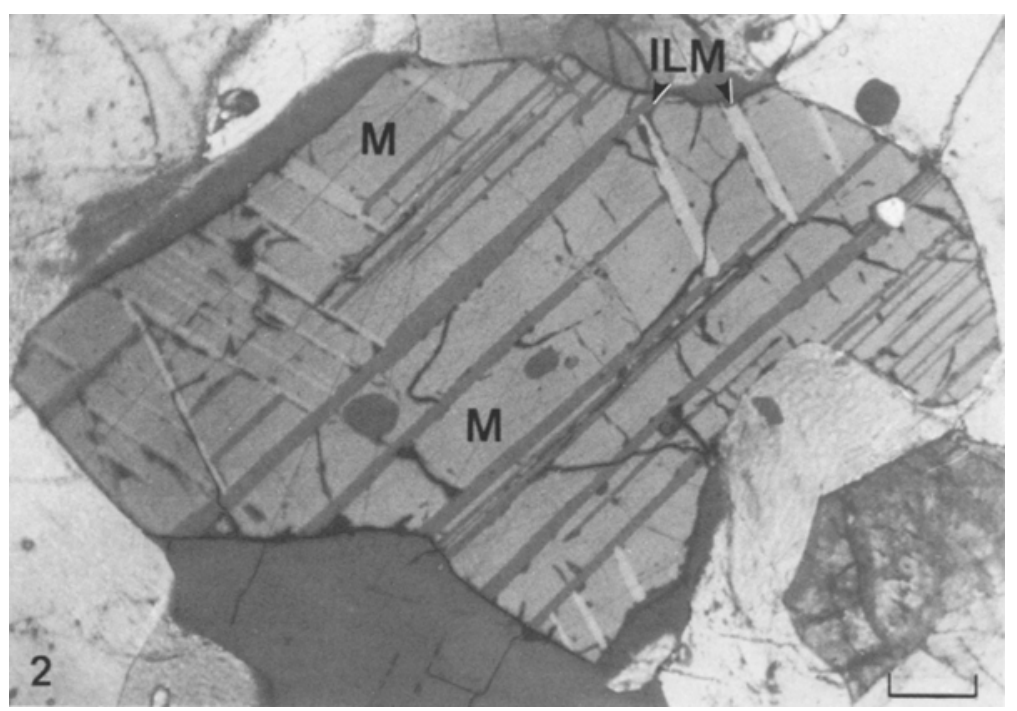

Fig. 2. Trellis-type ilmenite $(I L M)$ "exsolution" in magnetite $(M)$. The bar at the lower right is $100 \mu$

for unmixing of an iron oxide phase. A fourth oxide texture observed in the Adirondacks cannot be attributed to any simple oxidation or reduction hypothesis. Magnetites and ilmenites in contact with each other may show inhomogeneity, with the iron content of the ilmenite increasing toward magnetite and the titanium content of magnetite increasing toward the ilmenite. The chemical variations may not always be dramatic, and care must be taken to insure the mineral pair is not mistakenly analyzed as a homogeneous oxide pair. This texture is rare in the Adirondacks in contrast to the nearly ubiquitous "exsolution" textures and is simply avoided for use as a thermometer.

If the interpretation that "exsolved" ilmenite was once ulvöspinel solid solution in magnetite in equilibrium with primary ilmenite during the peak metamorphic event is correct, then temperature and oxygen fugacity data can be obtained. This is accomplished by analyzing the two phases in exsolved ilmenite-magnetite intergrowths, calculating an original homogeneous ulvöspinel-magnetite solid solution composition and applying it and the primary ilmenite composition to curves by Buddington and Lindsley (1964). The following section describes a technique by which this may be accomplished.

Implict in this technique are a number of assumptions which should be stated at the outset. 1. Ilmenite in the same rock as magnetite-ilmenite "exsolutions" is assumed to have equilibrated with an original magnetite rich in ulvöspinel solid solution. 2. Ilmenite unassociated with magnetite-ilmenite "exsolution" is assumed not to have re-equilibrated with magnetite after ulvöspinel exsolution (and subsequent oxidation to ilmenite). 3. No ulvöspinel solid solution is "lost" by formation of descrete grains of ilmenite upon exsolution from magnetite and oxidation to ilmenite. 4. The volume of ilmenite inferred from 
point counting magnetite-ilmenite intergrowths is representative of the true volume when several grains are point-counted and averaged.

\section{Analytical Procedure}

Major and minor element analyses were obtained using an ARL-EMX electron microprobe analyzer with wavelength dispersive PET, LIF and RAP crystal spectrometers. An accelerating potential of $15 \mathrm{keV}$ and an emission current of $150 \mu \mathrm{A}$ were standard operating conditions. Sample current ranged from 0.005 to $0.015 \mu \mathrm{A}$ and beam current was digitized with counting times of 25-35 seconds for all analyses. Natural ilmenite, hematite, rutile and synthetic manganese and vanadium oxides were used as probe standards. Spectrometer data reduced using the Fortran program EMPADR VII written by Rucklidge and Gasparrini (1969). In order to identify all major and minor elements present in each of the phases, emission spectra were obtained using an energy dispersive Li-silicon crystal and a multi-channel analyzer over a 500 second counting period under conditions which easily allow detection of heavy elements $(\geqq \mathrm{Na})$ at levels of $0.1 \mathrm{wt}$. \%. Extra care was taken to detect such elements as $\mathrm{Si}, \mathrm{Ca}, \mathrm{Cr}, \mathrm{V}$, and $\mathrm{Nb}$. Spectrometer data were obtained for these elements but together they constitute less than 0.1 weight $\%$ of any unknown. Analyses of selected grains are summarized in Tables 1 and 2.

In order to reintegrate ilmenite lamellae in magnetite to form a theoretical homogeneous titaniferous magnetite one must first choose samples with homogeneous magnetites and homogeneous ilmenite lamellae. Reconstitution becomes difficult if there are chemical variations across lamellae or host magnetite. Microprobe analyses are first obtained of the magnetite, ilmenite lamellae and individual ilmenite unassociated with magnetite. Reflected light pictures of the same magnetiteilmenite grains are taken and enlarged. The writers found that a transparency of a Zippatone dot pattern placed over the photograph and subsequent point counting over an entire grain gave good results. Due to differences in grain orientation a number of grains in each rock are analyzed and point counted to ensure statistically accurate results.

The number of counts depends on the size of the original grains (in the materials studied this ranged between $0.1-1.0 \mathrm{~mm}$ ) and the photographic enlargement. The writers counted in excess of 3000 points for most grains and in excess of 2500 points for all magnetite-ilmenite intergrowths. This places sampling error at less than 2\% following curves by Van Der Plas and Tobi (1965). Generally between 3 and 6 grains from each rock were point-counted and the volumes averaged to obtain a final "exsolved" ilmenite volume. The volume of ilmenite can then be converted to a weight fraction by calculating the densities of exsolved ilmenite and host magnetite and multiplying them by their respective volume percents to obtain weight fractions. The formulae for density determinations,

$$
\begin{aligned}
\rho= & \left(\mathrm{X}_{\text {ilmenite-hematite ss }}\right)\left(\rho_{\text {il menite-hematite ss }}\right)+\sum \mathrm{X}_{\mathrm{A}} \rho_{\mathrm{A}} \\
\rho= & \left(\mathrm{X}_{\text {magnetite-ulvöspinel ss }}\right) \quad\left(\rho_{\text {magnetite-ulvöspinel ss }}\right)+\sum \mathrm{X}_{\mathrm{B}} \rho_{\mathrm{B}} \\
& \text { where A and } \mathrm{B} \text { are additional components }
\end{aligned}
$$

take into account nonlinear densities which can be calculated from Lindsley's (1965) volume data on ulvöspinel-magnetite and ilmenite-hematite solid solutions. The weight fractions are multiplied by their respective Ti-poor magnetite and ilmenite analyses. Elemental weight percentages are then combined to yield a theoretical homogeneous ulvöspinel-rich magnetite solid solution.

Calibration of the magnetite-ilmenite geothermometer by Buddington and Lindsley was accomplished for systems containing only titanium, iron and oxygen. The magnetites and ilmenites of the Adirondacks typically have minor though significant amounts of additional components such as manganese, aluminum and magnesium. It is not obvious how to deal with these other components. It is also unclear how best to recalculate ferrous-ferric ratios from total iron microprobe analyses. To account for the ferrous-ferric problem we have adopted a technique of normalizing about the cations and maintaining charge balance by converting ferrous iron to ferric. Hence for our spinels $\mathrm{R}^{3+}=2 \mathrm{R}^{2+}-4 \mathrm{R}^{4+}, \sum \mathrm{Fe}=\mathrm{Fe}^{2+}+\mathrm{Fe}^{3+}$, and $\mathrm{Fe}^{3+}=2 \sum \mathrm{Fe}+2 \mathrm{Mg}+2 \mathrm{Mn}-4 \mathrm{Ti}-$ $\mathrm{A} 1-\mathrm{Cr}$. Recalculation of the proper weight percentage of $\mathrm{FeO}$ to $\mathrm{Fe}_{2} \mathrm{O}_{3}$ yields wt \% totals very near the ideal value of $100 \%$ (Table 2). The problem of impurities is solved in the following way. First additional components are calculated as $\mathrm{R}_{2} \mathrm{O}_{3}$ and $\mathrm{R}_{3} \mathrm{O}_{4}$ solutions in ilmenite and 
Table 2. Magnetite and reintegrated magnetite compositions from the Adirondack Highlands

\begin{tabular}{|c|c|c|c|c|c|c|c|c|}
\hline & TP-5 & $\begin{array}{l}\text { TP-5 } \\
\text { Reint }\end{array}$ & TP-11 & $\begin{array}{l}\text { TP-11 } \\
\text { Reint }\end{array}$ & IN-10 & $\begin{array}{l}\text { IN-10 } \\
\text { Reint }\end{array}$ & $N-5$ & $\begin{array}{l}\text { N-5 } \\
\text { Reint }\end{array}$ \\
\hline $\mathrm{TiO}_{2}$ & 0.63 & 10.78 & 0.33 & 9.32 & 0.25 & 10.87 & 0.75 & 11.01 \\
\hline $\mathrm{Al}_{2} \mathrm{O}_{3}$ & 1.11 & 1.50 & 1.48 & 1.25 & 0.47 & 0.73 & 1.24 & 1.05 \\
\hline $\mathrm{FeO}$ & 92.63 & 82.64 & 92.05 & 83.81 & 91.88 & 81.71 & 91.49 & 82.34 \\
\hline $\mathrm{FeO}^{\mathrm{a}}$ & 32.10 & 40.83 & 31.62 & 39.13 & 31.76 & 40.19 & 31.88 & 41.06 \\
\hline $\mathrm{Fe}_{2} \mathrm{O}_{3}$ & 67.19 & 46.10 & 67.08 & 49.59 & 66.74 & 46.09 & 66.16 & 45.82 \\
\hline $\mathrm{MnO}$ & 0.00 & 0.43 & 0.15 & 0.41 & 0.00 & 0.55 & 0.05 & 0.24 \\
\hline $\mathrm{MgO}$ & 0.01 & 0.04 & 0.01 & 0.03 & 0.00 & 0.04 & 0.01 & 0.01 \\
\hline SUM & 94.37 & 95.39 & 93.98 & 94.82 & 92.61 & 93.91 & 93.54 & 94.75 \\
\hline SUM & 101.0 & 99.68 & 100.7 & 99.74 & 99.22 & 98.47 & 100.1 & 99.29 \\
\hline \multicolumn{9}{|c|}{ Formulae normalized about 3 cations } \\
\hline $\mathrm{Fe}^{2+}$ & 1.017 & 1.290 & 1.004 & 1.270 & 1.017 & 1.294 & 1.018 & 1.309 \\
\hline $\mathrm{Fe}^{3+}$ & 1.916 & 1.321 & 1.917 & 1.450 & 1.933 & 1.337 & 1.903 & 1.316 \\
\hline $\mathrm{Ti}$ & 0.018 & 0.306 & 0.009 & 0.272 & 0.021 & 0.315 & 0.021 & 0.318 \\
\hline $\mathrm{Mn}$ & 0.000 & 0.014 & 0.004 & 0.002 & 0.000 & 0.018 & 0.002 & 0.008 \\
\hline $\mathrm{Mg}$ & 0.000 & 0.002 & 0.000 & 0.000 & 0.004 & 0.003 & 0.000 & 0.001 \\
\hline $\mathrm{Al}$ & 0.049 & 0.067 & 0.066 & 0.006 & 0.025 & 0.033 & 0.056 & 0.048 \\
\hline$\%$ USP & 1.8 & 31.6 & 0.9 & 27.3 & 2.1 & 32.0 & 2.2 & 32.6 \\
\hline
\end{tabular}

a Total iron as FeO. The amount of $\mathrm{Fe}_{2} \mathrm{O}_{3}$ is calculated from stoichiometry. The sum of the oxides is calculated for total iron as $\mathrm{FeO}$ and for the calculated wt. \% $\mathrm{Fe}_{2} \mathrm{O}_{3}$ (bottom sum)

magnetite respectively. In ilmenite, $\mathrm{Al}, \mathrm{Mg}$ and $\mathrm{Mn}$ are calculated as corundum, geikielite and pyrophanite respectively. In magnetite $\mathrm{Al}, \mathrm{Mg}$ and $\mathrm{Mn}$ form hercynite, spinel and galaxite respectively. The molar ratio of only $\mathrm{Fe}_{2} \mathrm{TiO}_{4} /\left(\mathrm{Fe}_{3} \mathrm{O}_{4}+\mathrm{Fe}_{2} \mathrm{TiO}_{4}\right)$ and $\mathrm{Fe}_{2} \mathrm{O}_{3} /\left(\mathrm{Fe}_{2} \mathrm{O}_{3}+\mathrm{FeTiO}_{3}\right)$ are used in obtaining oxygen fugacity and temperature data from the experimental curves of Buddington and Lindsley. Essentially this technique accounts for additional components as inert dilutents in the $\mathrm{Fe}-\mathrm{Ti}-\mathrm{O}$ system. Although there are preliminary data indicating this is not the case (Pinkney and Lindsley, 1976), it seems the most reasonable solution from a thermodynamic viewpoint lacking more complete data. The scheme for impurities described here differs slightly from the one proposed by Carmichael (1967). Recalculation of ulvöspinel and hematite solid solutions in magnetite and ilmenite respectively by Carmichael's scheme does not change our results significantly for the impurity levels we report.

The pressure dependence of the magnetite-ilmenite thermometer has not been determined experimentally for the pressures of interest in the Adirondacks. The lack of pressure dependence up to 2 kilobars has been determined by Lindsley (1964). Calculations by Rumble (1971) suggest that this system may be insensitive to pressure up to 10 kilobars. The writers' own calculations based on dilution of magnetite-hematite equilibria also suggest a very small pressure dependence for this system because of the small $\Delta \mathrm{V}$ solid of the reaction. For these reasons no pressure correction has been applied to the data.

\section{Analytical Results}

Compositions of ilmenites and titaniferous magnetites plotted on Buddington and Lindsley's $f_{\mathrm{O}_{2}}-T$ diagram (Fig. 3 ) indicate that metamorphic temperatures in the Adirondack Highlands range between $620^{\circ} \mathrm{C} \pm 50^{\circ} \mathrm{C}$ in the western Adirondacks to $790^{\circ} \mathrm{C} \pm 50^{\circ} \mathrm{C}$ in the central Adirondacks (Fig. 5). Oxygen fugacities 


\begin{tabular}{|c|c|c|c|c|c|c|c|}
\hline MM-13 & $\begin{array}{l}\text { MM-13 } \\
\text { Reint }\end{array}$ & SR-31 & $\begin{array}{l}\text { SR-31 } \\
\text { Reint }\end{array}$ & & $76-\mathrm{AS}-1$ & LB-1 & $\begin{array}{l}\text { LB-1 } \\
\text { Reint }\end{array}$ \\
\hline 0.83 & 11.37 & 0.38 & 15.58 & & 10.70 & 0.83 & 5.60 \\
\hline 0.42 & 0.62 & 0.49 & 0.38 & & 1.04 & 0.42 & 0.43 \\
\hline 92.02 & 82.05 & 92.76 & 79.30 & $\stackrel{\Xi}{=}$ & 82.95 & 92.02 & 87.74 \\
\hline 31.83 & 41.03 & 31.52 & 44.76 & 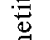 & 41.27 & 31.13 & 35.95 \\
\hline 66.82 & 45.54 & 67.97 & 38.34 & 苟 & 46.26 & 67.59 & 57.49 \\
\hline 0.00 & 0.28 & 0.03 & 0.32 & $\sum_{\Sigma}^{\pi}$ & 0.03 & 0.00 & 0.14 \\
\hline 0.03 & 0.05 & 0.01 & 0.18 & 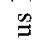 & 0.00 & 0.03 & 0.03 \\
\hline 93.30 & 94.37 & 93.67 & 95.74 & 5 & 92.81 & 93.30 & 93.94 \\
\hline 99.93 & 98.88 & 100.4 & 99.54 & 串 & 99.30 & 100.0 & 99.64 \\
\hline 1.022 & 1.316 & 1.010 & 1.419 & O & 1.313 & 1.004 & 1.160 \\
\hline 1.933 & 1.316 & 1.956 & 1.095 & $\stackrel{\vec{\Delta}}{\circ}$ & 1.326 & 1.964 & 1.668 \\
\hline 0.024 & 0.328 & 0.011 & 0.444 & $\stackrel{0}{\xi}$ & 0.313 & 0.004 & 0.163 \\
\hline 0.000 & 0.009 & 0.001 & 0.009 & $\stackrel{E}{0}$ & 0.000 & 0.000 & 0.005 \\
\hline 0.002 & 0.003 & 0.000 & 0.016 & & 0.000 & 0.000 & 0.002 \\
\hline 0.019 & 0.028 & 0.022 & 0.017 & & 0.048 & 0.028 & 0.002 \\
\hline 2.4 & 33.3 & 1.1 & 44.8 & & 32.1 & 0.2 & 16.3 \\
\hline
\end{tabular}

range from $10^{-16}$ to $10^{-19}$ but always lie within $10^{ \pm 1}$ of the fayalite-quartzmagnetite buffer. The shift of the QFM buffer in $f_{\mathrm{O}_{2}}-T$ space due to pressure and the partitioning of $\mathrm{Ti}$ into magnetite are opposite in effect and approximately cancel each other. For this reason the QFM buffer shown in Figure 3 is taken from Eugster and Wones (1962) and is not corrected for pressure or solid solutions in magnetite. Original error estimates by Buddington and Lindsley were $\pm 50^{\circ} \mathrm{C}$ and the writers believe this is a reasonable error estimate.

\section{Coexisting Feldspar Geothermometry}

Coexisting alkali and plagioclase feldspars occur in a wide variety of rocks in the Adirondack Highlands. Stormer's (1975) two-feldspar thermometer has been shown to be consistent with other thermometers, and gives geologically reasonable temperatures for volcanic rocks (Stormer, 1975), epizonal and mesozonal granites (Whitney et al., 1975; Whitney and Stormer, 1976) and granulite facies metamorphic rocks (Stormer and Whitney, 1975). Applications of this thermometer to the Adirondacks is extremely difficult due to the ubiquitous coarsely exsolved perthites, antiperthites and retrograde equilibration of the feldspars. The writers have found that homogeneous plagioclase coexisting with very homogeneous microcline in both the metaigneous and metasedimentary 


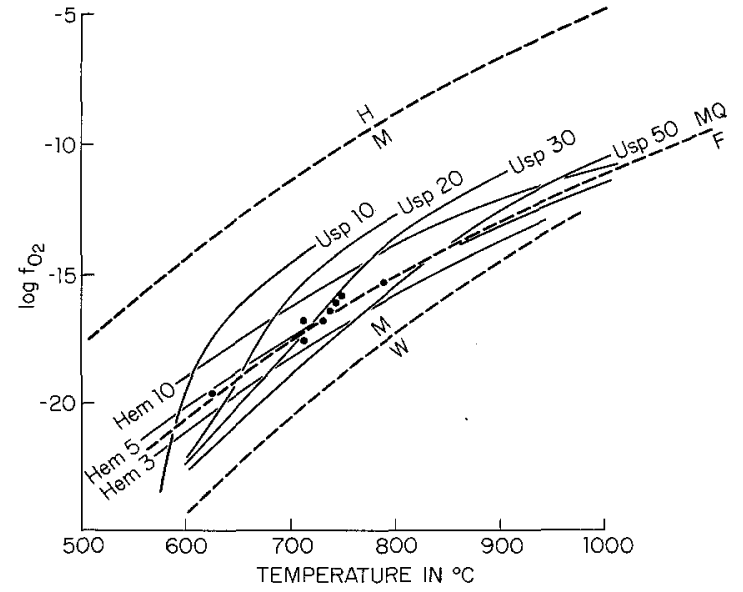

Fig. 3. $f_{\mathrm{O}_{2}}-T$ diagram for the iron-titanium oxides, after Buddington Lindsley, 1964. Plotted points represent coexisting oxides from the Adirondacks

rocks (in particular the gabbroic anorthosite and marble where Kspar is stable) give unreasonably low metamorphic temperatures of $300^{\circ}$ to $500^{\circ} \mathrm{C}$ for the central Adirondacks. The microtextures give no indication that the 2 feldspars were not in equilibrium as commonly they form $120^{\circ}$ triple-point intersections. Most often there is no other indication of disequilibrium such as myrmekitic intergrowths or overgrowths of any type. We conclude that these homogeneous feldspar pairs completely back-reacted to yield retrograde metamorphic temperatures.

The presence of exsolution textures and the techniques required to deal with the problem in obtaining feldspar temperatures has been discussed by Whitney and Stormer (1976). It is clear, however, that these workers did not have to reintegrate very coarse (up to $0.1 \mathrm{~mm}$ blebs or lamellae) exsolved albite in alkali feldspars. Defocussing of the electron microprobe beam to 20 microns was sufficient for Whitney and Stormer (1976) to obtain an average analysis of the alkali feldspar and hence a reproducible two-feldspar temperature. Any errors arising from matrix effects were ignored. Obtaining average alkali feldspar analyses on the very coarse perthites found in the Adirondacks is a time-consuming task as the beam defocussing technique employed by Stormer and Whitney (1976) is unsatisfactory. The procedure the writers followed is outlined in the following section.

\section{Analytical Procedure}

Feldspar analyses were obtained using electron microprobe techniques similar to those described previously. An accelerating voltage of $10 \mathrm{keV}$ and a sample current of $0.02 \mu \mathrm{A}$ were used in the analysis of $\mathrm{Ca}, \mathrm{Na}, \mathrm{K}, \mathrm{Si}, \mathrm{Fe}$ and $\mathrm{Al}$ in order to assure that volatilization of $\mathrm{Na}$ would not occur. Natural well-analyzed anorthoclase (Irving, personal communication) and $\mathrm{An}_{52}$ (Kerrick, personal communication) feldspars were used as microprobe standards. The beam current was digitized, and counting times ranged between 30 and $45 \mathrm{sec}$. All feldspar unknowns were checked for the presence of $\mathrm{Ba}, \mathrm{Mn}$, and $\mathrm{Mg}$. These elements combined did not constitute greater than 
0.01 weight percent of any feldspar analyzed. Spectrometer data was corrected by using the program EMPADR VII (Rucklidge and Gasparini, 1969).

Since the microprobe beam could not be defocussed to the $800-1000 \mu$ necessary in order to average exsolved albite lamellae in Kspar (due to errors from variations in emission X-ray take-off angle and matrix effects), another solution to the problem was sought. The writers first attempted to reintegrate the albite lamellae by the photographic technique previously described for magnetite-ilmenite intergrowths. For most samples this proved unsatisfactory. Boundaries between Na-rich lamellae and K-rich host are not always sharp. In addition, the Kspar is not always homogeneous and has slight, though important, variations in $\mathrm{Na}$ content. Both homgeneous lamellae and host and sharp chemical boundaries are essential for accurate reintegration by the photographic technique. Lacking these requirements, an alternate technique was required for alkali feldspar reintegration.

By point analyzing exsolved alkali feldspar grains on the microprobe the writers found that a reintegrated feldspar analysis could be obtained. Depending on grain size between $100-200$ points were analyzed on each of a number of perthites in any given thin section. Because of grain orientation problems, between two and five perthite grains were analyzed in order to insure that analyses obtained by this microprobe reintegration technique was reproducible. Analyses obtained by this method are tabulated in Table 3 . For the very few rocks where average perthite analyses could be obtained by the photographic method as well as the microprobe technique agreement between the two methods was excellent. Obtaining analyses by the two techniques also provided an opportunity to evaluate possible matrix effect errors introduced during the averaging of microprobe data to obtain an average perthite analysis. During data collection the microprobe beam excites many areas of an alkali feldspar grain which may differ dramatically in their $\mathrm{K}-\mathrm{Na}$ compositions. The different compositions require different atomic number, absorption, and fluorescence corrections. Upon data reduction, however, the computer program computes corrections based on a homogeneous unknown. As a result small errors are introduced into the averaged analysis. These errors are avoided when the albite lamellae are reintegrated photographically. Since in the few rocks where both techniques could be employed the analyses were very similar, matrix effect errors are probably well within experimental error. As an additional check, average analyses obtained by reducing each counted point individually and then averaging the compositions do not differ substantially from the other techniques.

The microprobe reintegration technique is less suitable for reintegration of magnetite-ilmenite intergrowths. Because there is no way of knowing the exact beam location when analyzing oxides, pits, cracks, and other polish imperfections cannot always be avoided and microprobe reintegration can give erratic analyses. Additionally, because of substantially different atomic number, absorption and fluorescence corrections for magnetite and ilmenite, matrix errors can be important. For these reasons oxides are more easily and accurately reintegrated by the photographic technique discussed previously.

\section{Analytical Results}

In addition to consideration of non-ideality of alkali feldspars another improvement in results obtained using the feldspar thermometer proposed by Stormer (1975) is produced by considering the effect of pressure on the feldspar solvus. The coexisting feldspars in Table 3 can yield temperature data if metamorphic pressures can be evaluated. Pressure estimates for the Adirondacks range between 4 and 10 kilobars (Engel and Engel, 1962; Buddington, 1963; De Waard, 1967). The ubiquitous presence of sillimanite throughout the Adirondack Highlands and Lowlands provides limiting pressure maxima (Holdaway, 1971 and Richardson et al., 1968). Pressures can be restricted to less than 6, 8 and 10 kilobars at $600^{\circ}, 700^{\circ}$ and $800^{\circ} \mathrm{C}$ respectively. Data by De Witt and Essene (1975) on coexisting pyrite-sphalerite-pyrrhotite assemblages at Balmat, New York indi- 
Table 3. Coexisting plagioclase and alkali feldspars from the Adirondack Highlands

\begin{tabular}{|c|c|c|c|c|c|c|c|c|c|c|c|c|c|c|}
\hline & \multicolumn{2}{|c|}{ BM-15 } & \multicolumn{2}{|l|}{ TP-8 } & \multicolumn{2}{|l|}{ IN-11 } & \multicolumn{2}{|c|}{ SCH-17 } & \multicolumn{2}{|c|}{$\mathrm{MM}-2$} & \multicolumn{2}{|c|}{ SR-30 } & \multicolumn{2}{|l|}{ SR-31 } \\
\hline & $\mathrm{Kfs}$ & Plag & $\mathrm{Kfs}$ & Plag & $\mathrm{Kfs}$ & Plag & $\mathrm{Kfs}$ & Plag & $\mathrm{Kfs}$ & Plag & $\mathrm{Kfs}$ & Plag & $\mathrm{Kfs}$ & Plag \\
\hline $\mathrm{SiO}_{2}$ & 65.29 & 61.91 & 66.65 & 64.60 & 65.53 & 64.65 & 65.20 & 63.14 & 64.96 & 62.94 & 64.55 & 63.93 & 65.74 & 64.17 \\
\hline $\mathrm{Al}_{2} \mathrm{O}_{3}$ & 19.02 & 24.06 & 18.76 & 22.07 & 18.48 & 22.05 & 19.53 & 22.97 & 19.04 & 23.12 & 18.75 & 22.14 & 18.68 & 21.63 \\
\hline $\mathrm{Fe}_{2} \mathrm{O}_{3}$ & 0.05 & 0.05 & 0.08 & 0.02 & 0.19 & 0.15 & 0.11 & 0.05 & 0.22 & 0.05 & 0.00 & 0.00 & 0.44 & 0.12 \\
\hline $\mathrm{CaO}$ & 0.28 & 5.18 & 0.85 & 3.18 & 0.12 & 4.17 & 1.28 & 4.04 & 0.74 & 4.42 & 0.94 & 5.47 & 0.61 & 5.69 \\
\hline $\mathrm{Na}_{2} \mathrm{O}$ & 2.66 & 8.80 & 4.18 & 7.80 & 3.95 & 9.37 & 3.82 & 9.54 & 2.92 & 9.08 & 2.93 & 8.86 & 3.40 & 8.21 \\
\hline $\mathrm{K}_{2} \mathrm{O}$ & 12.91 & 0.25 & 10.28 & 0.34 & 10.85 & 0.30 & 9.18 & 0.29 & 12.14 & 0.54 & 13.19 & 0.25 & 10.50 & 0.19 \\
\hline SUM & 100.2 & 100.3 & 100.8 & 100.0 & 99.12 & 100.7 & 99.14 & 100.0 & 100.0 & 100.2 & 100.4 & 100.7 & 99.37 & 100.0 \\
\hline
\end{tabular}

Formulae normalized about 5 cations

\begin{tabular}{lrlllllllllllll}
$\mathrm{Ca}$ & 0.014 & 0.246 & 0.041 & 0.150 & 0.006 & 0.196 & 0.062 & 0.191 & 0.036 & 0.210 & 0.046 & 0.258 & 0.030 & 0.270 \\
$\mathrm{Na}$ & 0.235 & 0.756 & 0.364 & 0.838 & 0.350 & 0.798 & 0.337 & 0.819 & 0.259 & 0.780 & 0.261 & 0.757 & 0.299 & 0.704 \\
$\mathrm{~K}$ & 0.751 & 0.014 & 0.589 & 0.019 & 0.634 & 0.017 & 0.532 & 0.016 & 0.708 & 0.031 & 0.722 & 0.014 & 0.608 & 0.010 \\
$\mathrm{Fe}^{3+}$ & 0.002 & 0.002 & 0.003 & 0.000 & 0.007 & 0.006 & 0.004 & 0.002 & 0.009 & 0.002 & 0.000 & 0.000 & 0.016 & 0.004 \\
$\mathrm{Al}$ & 1.023 & 1.256 & 0.994 & 1.148 & 0.997 & 1.045 & 1.045 & 1.199 & 1.006 & 1.207 & 1.013 & 1.150 & 1.001 & 1.128 \\
$\mathrm{Si}$ & 2.978 & 2.742 & 2.995 & 2.850 & 3.000 & 2.840 & 2.961 & 2.796 & 2.970 & 2.787 & 2.959 & 2.816 & 2.985 & 2.839 \\
& & & & & & & & & & & & & & \\
$\% \mathrm{An}$ & 1.4 & 24.2 & 0.41 & 15.0 & 0.60 & 19.3 & 6.6 & 18.6 & 3.6 & 20.5 & 4.3 & 25.1 & 3.1 & 27.3 \\
$\% \mathrm{Ab}$ & 23.5 & 74.3 & 36.5 & 83.2 & 34.8 & 78.5 & 36.0 & 79.7 & 25.6 & 76.2 & 24.2 & 73.6 & 31.4 & 71.3 \\
$\% \mathrm{Or}$ & 75.1 & 1.4 & 59.1 & 1.9 & 63.9 & 1.7 & 56.9 & 1.6 & 70.0 & 3.0 & 71.5 & 1.4 & 63.8 & 1.0 \\
$\% \mathrm{Or}\left(\mathrm{Fe}^{3+}\right)$ & 0.2 & 0.2 & 0.3 & 0.0 & 0.7 & 0.5 & 0.4 & 0.2 & 0.9 & 0.2 & 0.0 & 0.0 & 1.7 & 0.4 \\
\hline
\end{tabular}

cate load pressures of $6.5 \mathrm{~kb} \pm 1 \mathrm{~kb}$. Experimental data by Smith (1971) indicate that the ferrosilite-rich orthopyroxenes (Fs 90-95) found in the Adirondack Highlands are stabilized over the compositionally equivalent fayalitic olivine-quartz assemblage by minimum pressures of $8 \pm 1$ kilobar, when components other than $\mathrm{FeSiO}_{3}-\mathrm{MgSiO}_{3}$ are accounted for properly. In addition, magnetite-ilmenite temperatures and $\mathrm{Al}_{2} \mathrm{SiO}_{5}$ occurrences restrict pressures to less than 9 kilobars for much of the Adirondack Highlands. Consequently we have plotted the distribution of $\mathrm{NaAlSi}_{3} \mathrm{O}_{8}$ in coexisting plagioclase-alkali feldspar pairs as determined by Stormer, 1975, assuming a load pressure of 8 kilobars (Fig. 4).

The data indicate that metamorphic temperatures range from $650 \pm 50^{\circ} \mathrm{C}$ to $750^{\circ} \pm 50^{\circ} \mathrm{C}$ for the Adirondack Highlands. Stormer (1975) estimated the accuracy of temperatures determined using feldspar thermometry to be $\pm 30^{\circ} \mathrm{C}$ under best conditions. The writers feel that $\pm 50^{\circ} \mathrm{C}$ is a reasonable error estimate due to difficulties in reintegrating exsolved perthites.

\section{Discussion}

Temperature data obtained from both thermometers is plotted on an outline map of the Precambrian of upper New York (Fig. 5). Agreement between them is excellent. It can also be seen that both thermometers give internally consistent, reproducible results. These temperatures indicate that the regional metamorphic 


\begin{tabular}{|c|c|c|c|c|c|c|c|c|c|c|c|c|c|}
\hline \multicolumn{2}{|l|}{ As- 10} & \multicolumn{2}{|l|}{$\mathrm{SC}-2$} & \multicolumn{2}{|l|}{$\mathrm{SC}-3$} & \multicolumn{2}{|c|}{$X Y-9$} & \multicolumn{2}{|c|}{$X Y-10$} & \multicolumn{2}{|c|}{$X Y-12$} & \multicolumn{2}{|c|}{ MM-18 } \\
\hline Kfs & Plag & $\mathrm{Kfs}$ & Plag & Kfs & Plag & Kfs & Plag & $\mathrm{Kfs}$ & Plag & $\mathrm{Kfs}$ & Plag & Kfs & Plag \\
\hline .4 & 67.53 & 65.08 & 63.69 & 65.72 & 63.54 & 65.28 & 63.30 & 65.04 & 63.75 & 65.49 & 63.65 & 64.61 & 59.91 \\
\hline 17.87 & 18.78 & 19.74 & 23.45 & 18.62 & 22.62 & 18.76 & 22.29 & 18.77 & 22.07 & 18.68 & 22.08 & 18.06 & 25.29 \\
\hline 0.00 & 0.00 & 0.00 & 0.00 & 0.07 & 0. & 0.08 & 002 & 0.12 & 0.06 & 0.08 & 0.04 & 0.00 & 0.00 \\
\hline 0.40 & 1.13 & 0 & 5. & 0 & 4.85 & 0 & 3.86 & 0.45 & 3.46 & 0.53 & 3.74 & 0.10 & 6.12 \\
\hline 5.52 & 11.65 & 2.81 & 8.26 & 3.03 & 8.86 & 4.03 & 9.31 & 3.70 & 9.56 & 4.37 & 9.41 & 1.15 & 8.32 \\
\hline 9.15 & 0.14 & 3.49 & 0.14 & 11.39 & 0.41 & 10.43 & 0.25 & 10.45 & 0.25 & 10.13 & 0.22 & 15.56 & 0.23 \\
\hline 99.44 & 99.24 & 100.6 & 101.1 & 99.65 & 100.3 & 99.23 & 99.03 & 98.54 & 99.15 & 99.28 & 99.15 & 99.48 & 99.87 \\
\hline
\end{tabular}

\begin{tabular}{rrrrrrrrrrrrrrr}
0.020 & 0.054 & 0.004 & 0.262 & 0.040 & 0.230 & 0.037 & 0.185 & 0.022 & 0.165 & 0.026 & 0.179 & 0.032 & 0.293 \\
0.486 & 0.999 & 0.192 & 0.700 & 0.268 & 0.759 & 0.357 & 0.805 & 0.330 & 0.825 & 0.387 & 0.813 & 0.104 & 0.720 \\
0.530 & 0.008 & 0.783 & 0.008 & 0.662 & 0.023 & 0.608 & 0.014 & 0.613 & 0.014 & 0.589 & 0.013 & 0.922 & 0.013 \\
0.000 & 0.000 & 0.000 & 0.000 & 0.002 & 0.001 & 0.003 & 0.007 & 0.005 & 0.002 & 0.003 & 0.001 & 0.000 & 0.000 \\
0.956 & 0.979 & 1.058 & 1.209 & 1.001 & 1.178 & 1.006 & 1.172 & 1.017 & 1.158 & 1.005 & 1.159 & 0.989 & 1.330 \\
3.018 & 2.987 & 2.960 & 2.785 & 2.996 & 2.806 & 2.984 & 2.824 & 2.988 & 2.838 & 2.988 & 2.834 & 3.000 & 2.673 \\
& & & & & & & & & & & & & & \\
1.9 & 5.1 & 0.4 & 27.0 & 4.1 & 22.7 & 3.7 & 18.3 & 2.3 & 16.4 & 2.6 & 17.8 & 3.0 & 28.6 \\
46.9 & 94.1 & 19.6 & 72.2 & 27.6 & 74.9 & 35.5 & 79.6 & 34.0 & 82.0 & 38.5 & 80.8 & 9.8 & 70.2 \\
51.2 & 0.8 & 80.0 & 0.8 & 68.1 & 2.3 & 60.5 & 1.4 & 63.2 & 1.4 & 58.6 & 1.3 & 87.2 & 1.2 \\
0.0 & 0.0 & 0.0 & 0.0 & 0.2 & 0.1 & 0.3 & 0.7 & 0.5 & 0.2 & 0.3 & 0.1 & 0.0 & 0.0 \\
\hline
\end{tabular}

temperature gradient was generally low across the Adirondack Highlands. Highest metamorphic temperatures $\left(740-790^{\circ} \mathrm{C}\right)$ appear to cluster near the western and southwestern portion of the Marcy Massif. Temperatures decrease gradually in all directions to the upper $600^{\circ} \mathrm{s}$ on the outlying portions of the Highlands. The $750^{\circ}, 700^{\circ}$ and $650^{\circ} \mathrm{C}$ isotherms have been approximately located on Figure 5 but much more data are needed to locate their positions more accurately. Because of the potential for rapid reequilibration of the feldspars and the potential for possible "loss" of ulvöspinel component in magnetite by granule exsolution, these temperatures may represent temperature minima. Additional work is needed to limit maximum metamorphic temperatures. Even though the temperature inferred may represent minima our temperature data are significantly $\left(50-100^{\circ} \mathrm{C}\right)$ higher than data obtained by Buddington and Lindsley (1964) in their original work on oxide thermometry.

As we stated in the beginning one must be extremely careful in the interpretation of textural relations among coexisting oxide phases. Oftentimes ulvöspinel solid solution is "lost" by exsolution and diffusion away from the magnetite grain boundary. If this granule exsolution is not seen in polished section or goes unnoticed, resulting temperatures will be low. The writers feel that in some cases Buddington and Lindsley analyzed some materials that had undergone partial granule exsolution. Since they used bulk separates, some of the ulvöspinel exsolved from the magnetite would have been separated and analyzed with the ilmenite, while external granules of low-Ti magnetite would have re- 


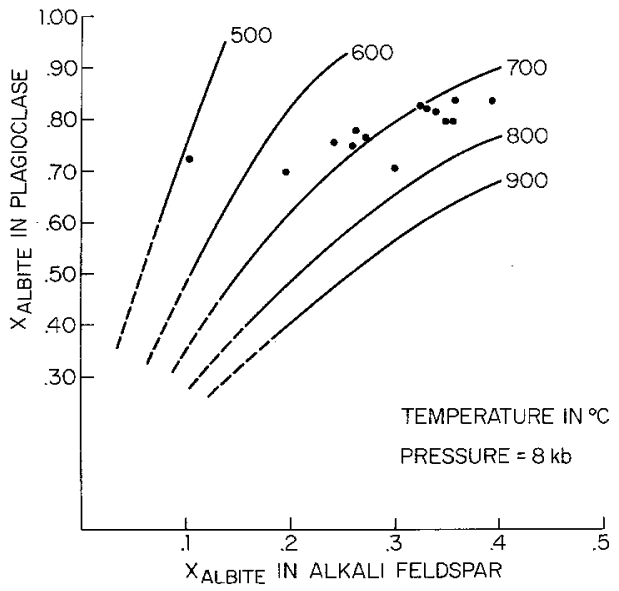

Fig. 4. Albite distribution between coexisting feldspars as a function of $\mathrm{P}-\mathrm{T}$, after Stormer, 1975. The Adirondack data are plotted

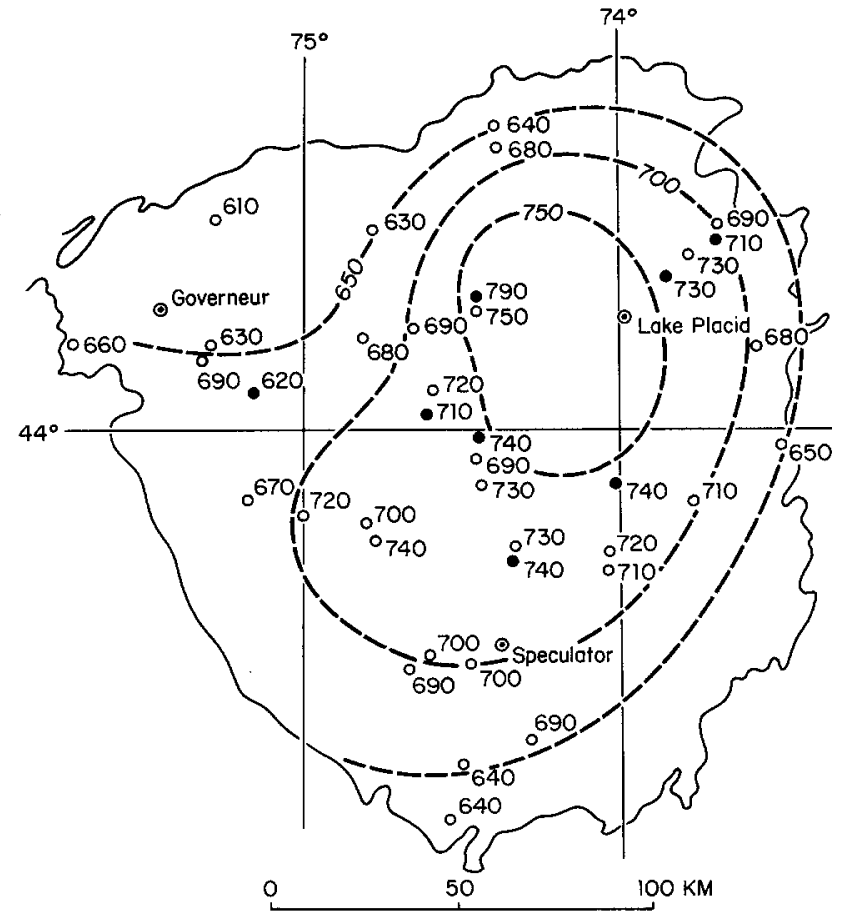

Fig. 5. Outline map of the PreCambrian terrane of Upper New York State showing metamorphic temperatures. Points indicated by $O$ and by $\bullet$ are temperatures obtained by feldspar and iron-titanium-oxide thermometry respectively

mained with the magnetic split. Since these external granules of oxides give low temperatures $\left(400^{\circ}-500^{\circ} \mathrm{C}\right)$, their effect on Buddington and Lindsley's thermometry would be to reduce the inferred temperatures. This may also account for the wide variations in temperatures found in and around the Sanford Lake Mine. Temperatures determined by Buddington and Lindsley (1964) in the ore body are $750^{\circ}$ while the surrounding country rock yielded temperatures of $650^{\circ} \mathrm{C}$. 


\section{Summary and Conclusions}

The data indicate that consistent, geologically reasonable temperatures can be obtained from reequilibrated textures in the magnetite-ilmenite and two feldspar systems. The techniques required to reintegrate exsolution lamellae and host into a homogeneous phase are tedious, time-consuming tasks requiring careful petrographic observation and interpretation. One must be aware of assumptions made in employing these techniques and critically evaluate their validity through each phase of the procedure. Temperatures obtained by these techniques may represent true peak metamorphic temperature or may merely be minimum temperatures. For this reason it is desirable to constrain upper temperature limits where possible.

Acknowledgments. The writers are grateful for the support of NSF Grant No. 014573, GSA Penrose Research Grant No. 2003-75, The Turner Fund-University of Michigan, without which this work could never have been started. We wish to thank Dr. W.C. Bigelow, Ms. P. Hollingsworth, and Mr. L. Allard of the Engineering College, University of Michigan for providing first rate microprobe facilities and assistance during data collection. We also thank Dr. D.R. Peacor and Dr. W.C. Kelly for their stimulating discussions and critical reviews of the manuscript.

\section{Appendix I}

Specimen Descriptions and Locations

Rocks containing variable amounts of plagioclase (An 10-30), alkali feldspar (Or 59-87), quartz, orthopyroxene (Fs 50-80), garnet, pargasitic hornblende, \pm magnetite, ilmenite, biotite, apatite, and zircon:

$\begin{array}{ll}\text { TP-5 } & \text { Rt. 30, 1.2 mi NW of Long Lake, Blue Mtn Lake Quad. } \\ \text { IN-11 } & \text { Rt. 10, } 0.5 \mathrm{mi} \mathrm{S} \text { of Sabael, Indian Lake Quad. } \\ \text { BM-15 } & \text { Rt. 28N, 1.0 mi SW of Long Lake, Blue Mtn. Lake Quad. } \\ \text { SCH-17 } & \text { Allard Hill, Schroon Lake Quad. }\end{array}$

Rocks containing plagioclase (An 10-30), alkali feldspar (Or 59-80), quartz, \pm pargasitic hornblende, magnetite, ilmenite, zircon, apatite-garnet, ortho- and clinopyroxene rarely present:

SC-2 South side of Humbug Mtn., Santa Clara Quad.

SC-3 East side of Lake Duane, Santa Clara Quad.

XY-9 $\quad 0.2 \mathrm{mi} \mathrm{S}$ of Stillwater Resevoir, Number Four Quad.

XY-10 $\quad 0.5 \mathrm{mi} \mathrm{N}$ of Eagle Bay, Big Moose Quad.

XY-12 Rt.28, $0.7 \mathrm{mi}$ E of Eagle Bay, Big Moose Quad.

LB-1 $\quad 0.5 \mathrm{mi}$ of Remington Corners, Lake Bonapart Quad.

76-AS-1 Rt. 9N, 1,5 mi NE of Au Sable Forks, Au Sable Forks Quad.

TP-8 $0.5 \mathrm{mi} \mathrm{NW}$ of Sperry Pond, Tupper Lake Quad.

AS-10 Rt. 9N, $1.5 \mathrm{mi} \mathrm{NE}$ of Au Sable Forks, Au Sable Forks Quad.

Rocks containing variable amounts of plagioclase (An 25-50), orthopyroxene (Fs 50-90), clinopyroxene (Hd 35-75), almandine-rich garnet, quartz, pargasitic hornblende, \pm alkali feldspar, biotite, apatite, zircon, ilmenite, and magnetite:

TP-11 Between Round Lake and Little Tupper Lake, Tupper Lake Quad.

N-5 Rt. $28 \mathrm{~N}, 6 \mathrm{mi}$ ESE of Newcomb near Roosevelt Hill, Newcomb Quad.

SR-30 Along railroad tracks $1 \mathrm{mi}$ SE of Deer Pond, St. Regis Quad.

SR-31 Along railroad tracks $1.5 \mathrm{mi}$ SE of Deer Pond, St. Regis Quad. 
MM-2

MM-13

MM-18
Rt.86, $1.7 \mathrm{mi}$ NE of Lake Placid, Lake Placid Quad.

Rt. between Upper Jay and Wilmington, $0.7 \mathrm{mi}$ SE of Kilburn School, Lake Placid Quad.

\section{References}

Barth, T.F.W.: Polymorphic phenomena and crystal structure. Am. J. Sci. 5, 273 (1934)

Barth, T.F.W.: The feldspar geological thermometers. Neues Jahrb. Mineral. Abhandl. 82, 143-154 (1957)

Barth, T.F.W.: The feldspar, geologic thermometer. Norsk Geol. Tidsskr. B42, 330-339 (1962)

Barth, T.F.W.: Additional data for the two-feldspar geothermometer. Lithos 1, 305-306 (1969)

Buddington, A.F.: Adirondack igneous rocks and their metamorphism. Mem. Geol. Soc. Am. 7, pp. 354 (1939)

Buddington, A.F.: Isograds and the role of $\mathrm{H}_{2} \mathrm{O}$ in metamorphic facies of orthogneisses of the northwest Adirondack area, New York. Bull. Geol. Soc. Am. 74, 1155-1182 (1963)

Buddington, A.F.: The occurrence of garnet in the granulite-facies terrane of the Adirondack Highlands, a discussion. J. Petrol. 7, 331-335 (1966)

Buddington, A.F., Fahley, J., Vlisidis, A.: Degree of oxidation of Adirondack iron oxide and iron-titanium oxide minerals in relation to petrogeny. Am. J. Sci. 253, 497-532 (1963)

Buddington, A.F., Leonard, B.F.: Regional geology of the St. Lawrence County magnetite district, northwest Adirondacks, New York, Prof. Paper U.S. Geol. Surv. 376, pp. 145 (1962)

Buddington, A.F., Lindsley, D.H. : Iron-titanium oxide minerals and synthetic equivalents. J. Petrol. 5, 310-357 (1964)

Carmichael, I.S.E.: The iron-titanium oxides of sialic volcanic rocks and their associated ferromagnesian silicates. Contrib. Mineral. Petrol. 14, 34-64 (1967)

De Witt, D.B., Essene, E.J.: Sphalerite geobarometry on Grenville marbles. Geol. Soc. Am. Abstr. with Program, 6, 709 (1974)

Engel, A.E.J., Engel, C.G.: Progressive metamorphism and granitization of the major paragneiss, northwest Adirondack Mountains, New York: Part 1, Total rock. Bull. Geol. Soc. Am. 69, 1369-1414 (1958)

Engel, A.E.J., Engel, C.G.: Progressive metamorphism of amphibolite, northwest Adirondack Mountains, New York. In: Petrologic studies: A volume in honor of A.F. Buddington (A.E.J. Engel, H.L. James, B.F. Lconard, eds.), Geol. Soc. Am., 37-82 (1962)

Holdaway, M.J.: Stability of andalusite and the aluminum silicate phase diagram. Am. J. Sci. 271, 97-131 (1971)

Lindsley, D.H.: Iron-titanium oxides. Carnegie Inst. Washington, Yearbook 64, 144-148 (1965)

Orville, P.M.: Comments on the two-feldspar geothermometer. Norsk. Geol. Tidsskr. 42, 340-346 (1962)

Perchuck, L.L., Ryabchikov, I.D. : Mineral equilibria in the system nepheline-alkali feldspar-plagioclase and their petrologic significance. J. Petrol. 9, 123-167 (1968)

Pinckney, L.R., Lindsley, D.H.: Effects of magnesium on iron-titanium oxides. Geol. Soc. Am. Abstr. with Program 8, 1051 (1976)

Richardson, S.W., Bell, P.M., Gilbert, M.C.: Kyanite-sillimanite equilibrium between $700^{\circ}$ and $1500^{\circ}$ C. Am. J. Sci. 266, 513-541 (1968)

Rucklidge, J.C., Gasparrini, E.L.: Specifications of a complete program for processing electron microprobe data : EMPADAR VII. Dept. of Geology, University of Toronto, unpublished circu$\operatorname{lar}(1969)$

Rumble, D., III: Thermodynamic analysis of phase equilibria in the system $\mathrm{Fe}_{2} \mathrm{TiO}_{4}-\mathrm{Fe}_{3} \mathrm{O}_{4}-\mathrm{TiO}_{2}$. Carnegie Inst. Washington Yearbook 69, 198-207 (1971)

Smith, D.: Stability of the assemblage iron-rich orthopyroxene-olivine-quartz. Am. J. Sci. 271, $370-382$ (1971)

Smith, D.: Pyroxene-olivine-quartz assemblages in rocks associated with the Nain Anorthosite Massif, Labrador. J. Petrol. 15, 58-78 (1974)

Stormer, J.C., Jr.: A practical two-feldspar thermometer. Am. Mineralogist 60, 667-674 (1975) 
Stormer, J.C., Jr., Whitney, J.A.: Geothermometry in sapphirine granulite: an evaluation of the two-feldspar and pyroxene methods. Trans. Am. Geophys. Union 56, 446 (1975)

Van der Plas, L., Tobi, A.C.: A chart for judging the reliability of point count results. Am. J. Sci. 263, 87-90 (1965)

Waard, D. de: The occurrence of garnet in the granulite-facies terrane of the Adirondack Highlands. J. Petrol. 6, 165-191 (1965a)

Waard, D. de: A proposed subdivision of the granulite facies. Am. J. Sci, 263, 455-461 (1965 b)

Waard, D. de: Absolute P-T conditions of granulite-facies metamorphism in the Adirondacks. Proc. Koninkl. Ned. Akad. Wetenschap., Ser. B 70, 400-410 (1967)

Waard, D. de: Facies series and P-T conditions of metamorphism in the Adirondack Mountains. Proc. Koninkl. Ned. Akad. Wetenschap., Ser B 71, 124-131 (1969)

Whitney, J.A., Smith, R.L.: Feldspar thermal histories for three post metamorphic granites from the Georgia Piedmont. Geol. Soc. Am. Abstr. with Program 7, 549 (1975)

Whitney, J.A., Stormer, J.C.: Geothermometry and geobarometry in epizonal granite intrusions: a comparison of iron-titanium oxides and coexisting feldspars. Am. Mineralogist 61, 751-761 (1976)

Wood, B.J., Strens, R.G.J.: The orthopyroxene geobarometer. Earth Planet. Sci. Lett. 11, 1-6 (1971)

Received February 24/Accepted April 5, 1977 